\title{
AN ASSESSMENT OF THE RELIABILITY OF DISCRIMINATORY MODELS ON THE BASIS OF THE BANKRUPTCY OF COMAPANIES IN THE FOOD INDUSTRY IN POLAND
}

\author{
Karolina Kozioł, MA ${ }^{1}$ \\ Rafał Pitera, $\mathrm{MA}^{2}$ \\ Uniwersytet Rzeszowski \\ Kolegium Nauk Spolecznych \\ Instytut Ekonomii i Finansów \\ M. Ćwiklińskiej 2, 35-601 Rzeszów, Poland \\ ${ }^{1}$ Katedra Ekonomiki i Zarządzania \\ e-mail:kakoziol@ur.edu.pl \\ ORCID: 0000-0002-2195-6373 \\ ${ }^{2}$ Katedra Finansów i Rachunkowości \\ e-mail: rpitera@ur.edu.pl \\ ORCID: 0000-0001-9598-1240
}

Received 29 October 2019, Accepted 31 March 2020

\begin{abstract}
Research background: The widespread occurrence of the phenomenon of bankruptcy leads to an analysis of the scale and causes of this phenomenon in Polish conditions. It should be remembered that the features that inextricably accompany the conduct of any business are uncertainty and risk, hence the phenomenon of the bankruptcy of enterprises is not foreign and it is impossible to eliminate.

Purpose: Assessment of the credibility of Polish discriminatory models as a method of the early warning of bankruptcy of enterprises on a sample of enterprises from the Polish food industry.

Research methodology: Literature review and verification of 10 methods using a linear function of discrimination most frequently adopted by people dealing with bankruptcy issues and examination of the financial condition of companies. The food industry was subject to analysis and financial assessment regarding the forecast of the bankruptcy of companies in the process of empirical verification.

Results: The interpretation of the results was based on the financial statements of the survey sample consisting of 50 Polish companies ( 25 with a good financial condition and 25 that were bankrupt) which in the years 2005-2016 declared bankruptcy).

Novelty: The results are based on a sample of food industry companies point to the legitimacy of the research. The use of a linear discriminant function confirms the usefulness of early warning models (prognostic reliability around $70 \%$ ). The study presents a classification of models according to prognostic reliability.
\end{abstract}


Guided by the criterion of model credibility, one can use tools with high prognostic efficiency in assessing the financial situation.

Keywords: discriminatory analysis, assessment of reliability, company, bankruptcy forecast, risk

JEL classification: G33, G170

\section{Introduction}

The process of constant adaptation to the changing environment, its conditions or constantly growing requirements and preferences of clients are the challenges faced by companies, which are the basic entities that operate both on the domestic and international market. The phenomenon of bankruptcy is not foreign; it intensifies or is more noticeable by entrepreneurs and other market participants in times of recession, which favours undermined fiscal policy and, in extreme cases, leads to the insolvency of companies. Bankruptcy usually occurs when a company becomes insolvent, and if its liabilities exceed the value of its assets (Kuciński 2013, p. 2).

It is the market that verifies which company is able to stay solvent, and which will collapse. Entities producing at higher costs and manufacturing products that are unsold are doomed either to be taken over by other more effective entities or to go bankrupt, because only those companies that are able to adapt to changing conditions remain on the market in the long run (Tokarski, 2012, p. 169). Significant from the viewpoint of naming correctness, the interchangeable use of the concepts of insolvency and bankruptcy is wrong, because in the first case the legal aspect is emphasized (regulated in Poland by the statute of 28 February 2003 - Bankruptcy and Reorganization Law; Journal of Laws no. 60, item. 535), while in the second case/we have to deal with the economic aspect, i.e. cessation of conducting business by an entrepreneur.

The phenomenon of the companies' bankruptcy is a kind of a natural regulator in the economic system, leading to a change of resources to more useful ones by the disappearance of companies that are not effective and which cannot withstand competition (Hadasik, 1998).

Considering the above transformations and the occurring phenomena, the article attempts to assess the validity and effectiveness of using discriminatory models as the most popular tools among the early warning methods used to assess the financial situation of companies in the 
food industry. A discriminatory analysis, used in this article, is a classic statistical method used in solving classification problems. It allows the solving of two basic problems (Dittmann et al., 2008, p. 265):

1. The selection of variables that define the best, the groups of "sick" and "healthy" companies - the procedure enabling the selection of variables from the list of potential explanatory variables.

2. The classification of new companies into the group of "healthy" and "sick" ones the procedure enabling the construction of a prognostic model in which some selected discriminatory variables appear as explanatory variables.

\section{Literature review}

Professional literature is rich in issues relating to the formation, continuity of processes and ways of using early warning methods for forecasting the bankruptcy of companies. Many authors, when assessing the degree of bankruptcy of the surveyed companies, use an analysis based on discriminatory models, which consist in reviewing the financial data presented by the company to make a comparison between them. In the current practice of forecasting the bankruptcy of companies, the following types of models are mainly used (Pociecha, 2014, p. 8):

- discriminatory models,

- logit models,

- neural networks,

- classification trees.

The first Polish discriminatory model to forecast bankruptcy was the model by E. Mączyńska. The author applied the multiplicative model of a simplified discriminatory analysis to predict the bankruptcy of Polish companies (Mączyńska, 1994). The model was formed by adjusting the Western model by E. Altman to Polish conditions.

A developed application of Fisher's discriminatory function (Fisher, 1936) is the bankruptcy forecast model for Polish companies presented in the work (Gajdka, Stos, 1996), where the sample of the surveyed industrial companies was 40 entities, half of which were bankrupt, and the other half "healthy" companies listed on the Warsaw Stock Exchange.

Among important analyses from the professional literature, one should cite the verification made by P. Antonowicz, who paid attention to the study on 52 discriminatory models, where the sample of surveyed entities consisted of bankrupt companies and companies with a good financial condition. The author studied 89 companies from the Pomeranian Province which in 2003-2004 
filed bankruptcy applications with the court. On the other hand, he counted 119 enterprises from the same province to the group of companies not threatened with bankruptcy and which were included in the Gazele Biznesu 2004 ranking (Antonowicz, 2004, p. 19). J. Siciński based on airline companies assessed the usefulness in forecasting the bankruptcy of early warning models (Siciński, 2018, pp. 263-277). The successor of this type of research was R. Balina who, based on financial data from 60 reports, assessed the reliability of discriminatory models. The 60 entities used in the study consisted of 30 bankrupt companies and 30 companies that were in good financial condition. The sample of the entities was composed of limited liability companies from the construction work sector (Balina, 2012, pp. 233-234). A. Dębicka carried out an in-depth analysis of early warning systems based on a sample of small and medium-sized enterprises (Dębicka, 2015, pp. 538-547). In turn, W. Lichota undertook the assessment of discriminatory models by conducting a survey on a sample of 8 companies from the Podkarpackie Province, which in 2003-2014 submitted to the court an application for the declaration of a liquidation bankruptcy (Lichota, 2017, pp. 212-213). G. Gołębiowski from A. Pląsek verified the effectiveness of discriminatory models with the example of the tourism industry (Gołębiowski, 2018, pp. 9-24). E. Grzegorzewska and H. Runowski, investigated the prognostic reliability of discriminatory models on the basis of a set of 51 breeding companies belonging to the Agricultural Real Estate Agency (Agencja Nieruchomości Rolnych (ANR)), selecting for each surveyed year 12 companies at risk and 12 companies that were in good condition, making a breakdown based on the value of 3 financial ratios (Grzegorzewska, Runowski, 2008, p. 84). R. Pitera assessed a company from the manufacturing industry using early warning models (Pitera, 2017, pp. 326-343). Early warning models were also used in the assessment of the financial situation of construction companies in the A. Banach-Kobyra study (BanachKobyra, 2015, pp. 9-17). J. Kisielińska and A. Waszkowski also assessed the effectiveness of discriminatory and logit models, basing their research on a sample of 16 expertly selected companies ( 8 entities with good financial standing and 8 bankrupt entities against which in 2009 the courts declared liquidation bankruptcy or with the possibility of making an arrangement with creditors). Companies from similar industries were added to the sample of companies that were in good condition (Kisielińska, Waszkowski, 2010, pp. 17-31). Using the discriminatory models, the financial situation of companies listed on NewConnect was assessed by A. Kuciński (2011, pp. 146-163). M. Hamrol and J. Chodakowski used early warning models based on the financial data of 36 companies listed on the Warsaw Stock Exchange, which in 2002-2004 filed applications for bankruptcy or arrangement proceedings (Hamrol, Chodakowski, 2008, p. 29). On the other hand, D. Zarzecki attempted to assess the forecasting effectiveness of discriminatory 
models. For this purpose, he used the empirical data of 21 companies - nine of them in a weak financial condition, and 12 as their healthy counterparts (Zarzecki, 2003, p. 179).

The research multitude of many authors and a large number of publications confirm the upward trend in the verification of corporate bankruptcy by means of early warning methods, which include discriminatory models, as the most popular tools for assessing the accuracy and effectiveness of bankruptcy forecasting.

Proof of this is the research by M.A. Aziz and H.A. Dara (2004); are a tool for forecasting the bankruptcy of companies, where discriminative models are the most commonly used (30.3\% of published papers), second most frequently used are logit models $(21.3 \%)$, third most neural networks $(9.0 \%)$ and in fourthly - classification trees only $(5.6 \%)$.

\section{Description of the sample and presentation of results}

The research sample consisted of data from 25 companies of the food processing industry, which in the years 2005-2016 declared bankruptcy (the judgement of the district court establishing liquidation bankruptcy). The second group of surveyed entities was companies classified as "healthy" - also 25 entities from the analogous industry. At the same time, it was attempted to match healthy companies with companies from the bankrupt group with similar activities, similar size and activity profile. Referring to the food industry, the two samples included the financial data from companies of the following branches:

- processing of fruit and vegetables, preserving of fish and meat, milk and potatoes,

- production of oils, fats and beverages, production of feed and sugar, sugar confectionery production, manufacture of tobacco products, production of food concentrates, production of other food products, manufacture of grain mill products.

The food sector is one of the most important and fastest growing branches of the Polish economy; enjoys great potential in the field of R\&D in the production of organic food, is characterized by a well-developed network of suppliers, and about $41 \%$ of the sector's production is exported abroad. Poland is a leading producer of, among others: fruit, meat (poultry, pork), dairy products and mushrooms; the food industry (since July 2014) has been "included" in the list of priority sectors for the Polish government; the industry is exposed to changes and fluctuations in the economic situation and exchange rates (Polska Agencja Inwestycji i Handlu).

Among the entities surveyed, the largest share were enterprises employing 50 to 100 employees (39\%). Next, were enterprises employing between 25 and 50 employees (33\%), followed by $100-200$ employees (26\%). The remaining $2 \%$ were enterprises employing up to 
25 employees. Most enterprises were located in the Mazowieckie voivodeship (20\%). Next in terms of the number of enterprises were companies from the Pomorskie (19\%), Lubelskie (17\%), Podkarpackie (15\%), Małopolskie (12\%), Zachodniopomorskie (8\%), Wielkopolskie $(5 \%)$ and Śląskie (4\%) voivodeships. In total, 50 entities located in 8 voivodeships constituted the sample.

Discriminatory models selected for the study were selected on the basis of several factors:

- the selection was based on choosing models constructed for enterprises operating in the conditions of the Polish economy,

- the selection was based on current literature on the subject - scientific positions on early warning models were analyzed in terms of their prognostic reliability - on this basis it was decided to choose methods with the highest prognostic values,

- because the research sample were enterprises from several voivodeships, models dedicated only to a particular voivodeship were omitted (for example the M. Kasjaniuk models).

Among these models the following methods have been very popular up to now:

- model by E. Mączyńska,

- model 4 by J. Gajdka and D. Stos,

- model by A. Hołda,

- model by M. Hamrol (the Poznań Model),

- model by T. Korol,

- the "G" Model of the Institute of Economic Sciences of the Polish Academy of Sciences [Instytut Nauk Ekonomicznych Polskiej Akademii Nauk - INE PAN] defined in the professional literature also as the model by E. Mączyńska and M. Zawadzki,

- model by J. Gajdka and D. Stos - modified model,

- model 1 by D. Appenzeller and K. Szarzec,

- model 1 by B. Prusak,

- model by T. Maślanka.

Table 1 shows the classification of verified discriminatory models according to the effectiveness of the resulting diagnoses. In addition, it shows the distribution of erroneous diagnoses into first- and second-degree errors. If a healthy entity was credited to a group of bankrupts, it is a first-degree error. In contrast, if a bankrupt company was credited to a group of healthy companies, it is called a second-degree error (Pociecha, 2007). 
Table 1. Classification of early warning models according to the relevance of the results for the last year of study

\begin{tabular}{|c|c|c|c|c|}
\hline \multirow{2}{*}{ Model } & \multirow{2}{*}{$\begin{array}{l}\text { Percentage } \\
\text { of accurate } \\
\text { forecasts }\end{array}$} & \multirow{2}{*}{$\begin{array}{c}\text { Number } \\
\text { of correct } \\
\text { assessments }\end{array}$} & \multicolumn{2}{|c|}{ Number of wrong assessments } \\
\hline & & & $1^{\text {st }}$ degree error & $2^{\text {nd }}$ degree error \\
\hline Poznań Model (by M. Hamrol) & 68 & 34 & 7 & 9 \\
\hline Model by T. Korol & 68 & 34 & 7 & 9 \\
\hline Model by J. Gajdka and D. Stos & 68 & 34 & 9 & 7 \\
\hline Model by D. Appenzeller and K. Szarzec & 68 & 34 & 8 & 8 \\
\hline Modified Model by J. Gajdka and D. Stos & 66 & 33 & 6 & 11 \\
\hline Model by A. Hołda & 64 & 32 & 6 & 12 \\
\hline $\begin{array}{l}\text { "G” INE PAN Model by E. Mączyńska a } \\
\text { nd M. Zawadzki }\end{array}$ & 64 & 32 & 8 & 10 \\
\hline Model by B. Prusak & 64 & 32 & 11 & 7 \\
\hline Model by T Maślanka & 54 & 27 & 6 & 17 \\
\hline Model by E Mączyńska & 52 & 26 & 7 & 17 \\
\hline
\end{tabular}

Source: own study on the basis of the research results.

These results represent the classification of the models used in the study. Noteworthy is the fact that each of the 10 models had a predictive reliability of over $50 \%$. However, it should be also added that in the same period, none of the models had above $70 \%$ efficiency. In the case of four models, their effectiveness was reported at $68 \%$ - which was the best result. The oldest model was the least effective model - created in 1994. It was a model constructed by E. Mączyńska. In this case, the modification of the model of 2006 proved to be a more reliable tool. In the opposite direction, the obtained diagnoses concerned the models by J. Gajdka and D. Stos - the primary model was characterized by the better effectiveness of forecasts than its subsequent modification.

\section{Conclusions}

The study conducted on a set consisting of 50 food industry enterprises and their verification using 10 methods using the linear discriminatory function and, consequently, the results obtained - confirm the usefulness of early warning models. Analysing the prognostic reliability of discriminatory models used for the study, 4 of them were characterized by almost $70 \%$ accuracy, and only 2 models of 50\% accuracy - for the model by E. Mączyńska - 52\% and $54 \%$ for the model by T. Maślanka. The differences in the results of individual models depend on many factors. Among others, from the financial indicators used, estimated parameters 
of explanatory variables, or the number of measures included in the model. The effectiveness of individual models is also influenced by the research sample - both the one on the basis of which the model was constructed, as well as the sample on the basis of which the model was verified. In the study, all models achieved values above 50\% efficiency, which may be evidence of their appropriate construction, as well as the possibility of their use in practice. In addition to high prognostic values, another advantage of the models is their simplicity in use. The advantage of early warning models is also the unambiguous diagnosis: "good financial condition" or "threat of bankruptcy". This result does not cause interpretation problems, such as the results of the traditional indicator analysis. An additional advantage of these models is their universality. This means that they can be used in the study of enterprises from various industries and located in different regions. However, it should be remembered that these models should be used to assess the financial condition of enterprises operating in the conditions of the Polish economy

It should be remembered that the discussed models should be used as one of many tools, not as the only ones. The diversification of a variety of methods will allow objective recognition of differences in the results of individual methods and contribute to the comprehensive assessment of the enterprise. It will also be more likely to get the correct diagnosis. A correct diagnosis of the results allows for making accurate and optimal decisions on which the existence of a company on the market depends.

\section{References}

Antonowicz, P. (2010). Zastosowanie macierzy klasyfikacji przedsiębiorstw do oceny zdolności predykcyjnych 52 modeli z-score [The Use of Classification Matrix of Companies to Assess the Predictive Ability of 52 Z-Score Models]. Zeszyty Naukowe Politechniki Rzeszowskiej, 272/1. Zarzadzanie i Marketing.

Appenzeller, D., Szarzec, K. (2004). Prognozowanie zagrożenia upadłością polskich spółek publicznych [Predicting the Bankruptcy Threat to Polish Public Limited Companies]. Rynek Terminowy, 1 .

Aziz, M.A., Dar, H.A. (2004). Predicting Corporate Bankruptcy, Whither do We Stand? 3rd Annual Meeting of the European Economics and Finance Society "Word Economy and European Integration”, University of Gdańsk, 13-16 May. 
Balina, R. (2012). Skuteczność wybranych modeli dyskryminacyjnych na przykładzie branży robót budowlanych [The Effectiveness of Selected Discriminatory Models on the Example of the Construction Works Industry]. Zeszyty Naukowe Uniwersytetu Szczecińskiego, 689. Finanse, Rynki finansowe, Ubezpieczenia, 50.

Banach-Kobyra, A. (2017). Analiza sytuacji przedsiębiorstw budowlanych w Polsce w latach 2007-2015. Annales, 51 (5).

Czajka, D. (1999). Przedsiębiorstwo w kryzysie - upadłość lub układ [The Company in Crisis - Bankruptcy or Arrangement. Warszawa: Wydawnictwo Zrzesz. Prawników Polskich.

Dębicka, A. (2015). Systemy wczesnego ostrzegania w zarządzaniu sytuacją kryzysową w małym i średnim przedsiębiorstwie. Zeszyty Naukowe Uniwersytetu Szczecińskiego, 848. Ekonomiczne Problemy Ustug, 116.

Dittmann, I., Dittmann, P., Szabela-Pasierbińska E., Szpulak, A. (2008). Prognozowanie w zarządzaniu przedsiębiorstwem. Kraków: Oficyna Wolters Kluwer Business.

Fisher, R. (1936). The use of multiple measurements in taxonomic problems. Annals, 31 of Eugenics, 7, 179-186.

Gajdka, J., Stos, D. (1996). Wykorzystanie analizy dyskryminacyjnej w ocenie kondycji finansowej przedsiębiorstw [The Use of Discriminatory Analysis in the Assessment of the Financial Condition of Companies]. In: R. Borowiecki (ed.), Restrukturyzacja w procesie przeksztatceń i rozwoju przedsiębiorstw [Restructuring in the Process of Transformation and Development of Companies]. Kraków: Akademia Ekonomiczna.

Gołębiowski, G., Pląsek, A. (2018). Skuteczność wybranych modeli dyskryminacyjnych na przykładzie branży turystycznej. Studia i Prace. Kolegium Zarządzania i Finansów, 164.

Grzegorzewska, E., Runowski, H. (2008). Zdolności prognostyczne polskich modeli dyskryminacyjnych w badaniu kondycji finansowej przedsiębiorstw rolniczych [Prognostic Capabilities of Polish Discriminatory Models in the Study of the Financial Condition of Agricultural Companies]. Roczniki Nauk Rolniczych, G Series, 95, Journal 3/4.

Hadasik, D. (1998). Upadłość przedsiębiorstw w Polsce i metody jej prognozowania [Bankruptcy of Companies and Methods of Forecasting It]. Zeszyty Naukowe, Series II: habilitation works, 153.

Hamrol, M., Czajka, B., Piechocki, M. (2004). Upadłość przedsiębiorstwa - model analizy dyskryminacyjnej [The Bankruptcy of the Company - Discriminatory Analysis Model]. Przegląd Organizacji, 6.

Hamrol, M., Chodakowski, J. (2008). Prognozowanie zagrożenia finansowego przedsiębiorstwa. Wartość predykcyjna polskich modeli analizy dyskryminacyjnej [Forecasting the Company's Financial Threat. The Predictive Value of Polish Models of Discriminatory Analysis]. Badania Operacyjne i Decyzje, 3. 
Hołda, A. (2001). Prognozowanie bankructwa jednostki w warunkach gospodarki polskiej z wykorzystaniem funkcji dyskryminacyjnej [Forecasting the Bankruptcy of an Entity in the Polish Economy Conditions, Using a Discriminatory Function] ZH. Rachunkowość, 5.

Kasjaniuk, M. (2006). Zastosowanie analizy dyskryminacyjnej do modelowania i prognozowania upadłości przedsiębiorstw [The Use of Discriminatory Analysis for Modeling and Forecasting the Bankruptcy of Companies]. Barometr Regionalny, 2 (6).

Kisielińska, J., Waszkowski, A. (2010). Polskie modele do prognozowania bankructwa przedsiębiorstw i ich weryfikacja [Polish Models for Forecasting the Bankruptcy of Companies and Their Verification]. Zeszyty Naukowe Szkoły Głównej Gospodarstwa Wiejskiego w Warszawie Ekonomika i Organizacja Gospodarki Żywnościowej, 82.

Korol, T. (2010). Systemy wczesnego ostrzegania przedsiębiorstw przed ryzykiem upadłości [Systems of Early Warning of Companies against the Risk of Bankruptcy]. Warszawa: Oficyna Wydawnicza Wolters Kluwer.

Kuciński, A. (2013). Niewypłacalność, upadłość przedsiębiorstw [Insolvency, Bankruptcy of Enterprises]. Studia i Prace Wydziału Ekonomicznego, 5.

Kuciński, A. (2011). Wykorzystanie wielowymiarowych modeli dyskryminacyjnych do oceny kondycji finansowej przedsiębiorstw na przykładzie wybranych spółek notowanych na rynku NewConnect [The Use of Multidimensional Discriminatory Models to Assess the Financial Condition of Companies on the Example of Selected Companies Listed on the NewConnect Market]. Studia i Materiaty Polskiego Stowarzyszenia Zarzadzania Wiedza, 41.

Lichota, W. (2017). Weryfikacja skuteczności diagnostycznej wybranych modeli analizy dyskryminacyjnej na przykładzie próby przedsiębiorstw z województwa podkarpackiego [Verification of Diagnostic Effectiveness of Selected Discriminatory Analysis Models on the Example of the Sample of Companies from the Podkarpackie Province]. Prace Naukowe Uniwersytetu Ekonomicznego we Wrocławiu, 472.

Maślanka, T. (2008). Przeptywy pieniężne $w$ zarządzaniu finansami przedsiębiorstw [Cash Flows in the Financial Management of Companies]. Warszawa: Wydawnictwo C.H. Beck.

Mączyńska, E. (1994). Ocena kondycji przedsiębiorstwa [Assessment of the Company’s Condition]. Życie Gospodarcze, 38.

Mączyńska, E., Zawadzki, M. (2006). Dyskryminacyjne modele predykcji bankructwa przedsiębiorstw [Discriminatory Models of Predicting a Company's Bankruptcy]. Ekonomista, 2.

Mączyńska, E. (2009b). Ocena ryzyka upadłości przedsiębiorstwa [Assessment of the Risk of the Company's Bankruptcy]. In: A. Fierla (ed.), Ryzyko w działalności przedsiębiorstw. Wybrane aspekt [Risk in Company Operations. Selected Aspects]. Warszawa: Oficyna Wydawnicza SGH.

Mączyńska, E., Morawska, S. (2015). Efektywność procedur upadłościowych. Bankructwa przedsiębiorstw. Katharsis $i$ nowa szansa [The Efficiency of Bankruptcy Procedu- 
res. Bankruptcies of Companies. Catharsis and a New Opportunity]. Warszawa: Oficyna Wydawnicza SGH.

Pitera, R. (2017). Metody oceny kondycji finansowej spółki akcyjnej. Studium przypadku. Prace Naukowe Uniwersytetu Ekonomicznego we Wroctawiu, 472.

Pociecha, J. (2007). Problemy prognozowania bankructwa firmy metodą analizy dyskryminacyjnej [The Problems of Predicting the Bankruptcy of a Company using the Method of Discriminatory Analysis]. Acta Universitatis Lodziensis Folia Oeconomica, 205.

Pociecha, J. (2014). Statystyczne metody prognozowania bankructwa w zmieniajacej się koniunkturze [Statistical Methods of Forecasting Bankruptcy in the Changing Economic Situation]. Kraków: Fundacja Uniwersytetu Ekonomicznego w Krakowie.

Pannert, M. (2010). Wpływ upadtości likwidacyjnej na wykonywanie zobowiazań z umów wzajemnych [The Impact of Liquidation Bankruptcy on Performing the Obligations of Mutual Agreements]. Warszawa: Wolters Kluwer Polska.

Polska Agencja Inwestycji i Handlu. (2019). Sektor spożywczy. Retrieved from: https://www. paih.gov.pl/sektory/spozywczy\# (5.04.2020).

Prusak, B. (2005). Nowoczesne metody prognozowania zagrożenia finansowego przedsiębiorstw [Modern Methods of Forecasting Financial Threats to Comapnies]. Warszawa: Difin.

Siciński, J. (2018). Wybrane systemy wczesnego ostrzegania w predykcji upadłości europejskich linii lotniczych w latach 2009-2017. Zarzadzanie i Finanse, 3 (1).

Stos, D., Gajdka, J. (2003). Ocena kondycji finansowej polskich spółek publicznych w okresie 1998-2001 [Assessment of the Financial Condition of Polish Public Companies in the Period 1998-2001]. In: D. Zarzecki (ed.), Czas na pieniadz. Zarzadzanie finansami. Mierzenie wyników i wycena przedsiębiorstw [Time for Money. Financial Management. Measuring Results and Evaluation of Companies]. Szczecin: Wydawnictwo Uniwersytetu Szczecińskiego.

Wajda, P. (2009). Wykorzystanie analizy dyskryminacyjnej w ocenie ryzyka upadłości przedsiębiorstw [The Use of Discriminatory Analysis in the Assessment of the Bankruptcy Risk of Companies]. Przeglad Corporate Governance, 1.

Wojnar, J. (2014). Ocena skuteczności modeli analizy dyskryminacyjnej do prognozowania zagrożenia finansowego spółek giełdowych [Evaluation of the Effectiveness of Discriminatory Analysis Models to Forecast the Financial Threat to Listed Companies]. Zeszyty Naukowe Matopolskiej Wyższej Szkoły Ekonomicznej w Tarnowie, 24 (1).

Zarzecki, D. (2003). Analiza dyskryminacyjna jako metoda oceny zagrożenia bankructwem ["Discriminatory Analysis as a Method of Assessment of Bankruptcy Threat"]. In: D. Zarzecki (ed.), Czas na pieniądz. Zarządzanie finansami. Mierzenie wyników i ocena przedsiębiorstw [Time for Money. Financial Management. Measuring Results and Evaluation of Companies]. Szczecin: Wydawnictwo Uniwersytetu Szczecińskiego. 